\title{
PUBLIC COST AND INTERNAL EFFICIENCY IN KWARA STATE PUBLIC SECONDARY SCHOOLS, NIGERIA
}

PROF. A. Y. ABDUlKareEM; DR. A. A. ATOlagbe; DR. OlaOlu. P. AKINNUBI AND DR. STEPHEN O. AFOLABI

\begin{abstract}
There are 187 public secondary schools in Kwara State, Nigeria out of which 100 were randomly selected. "Secondary Education Cost and Internal Efficiency Checklist" (SECIEC) was used to collect data. Five research questions and one hypothesis were raised and analysed using percentage and Pearson ProductMoment Correlation Coefficient at 0.05 alpha level. The study revealed that budgetary allocations as the main source of funds to secondary schools which dropped annually from $29.2 \%$ of total cost in 2005 to 7.7 $\%$ in 2009. A significant relationship existed between public cost and internal efficiency in the schools ( $r$ $=0.623 ; p \leq 0.05, d f=98$ ). It was recommended that government should mobilize special funds to expand and renovate the available school facilities.
\end{abstract}

Keywords: Public cost, internal efficiency, secondary schools

\section{Introduction}

The importance of education cannot be underscored in any society. Education is accepted as a veritable vehicle for national transformation in human history (Ijaiya, 2012). Education is an instrument per-excellence for the intellectual, moral and vocational development of the young members of a given society. In fact, no nation can rise above her investment in education. As elucidated by Olutola (1983), education is the key that unlocks the door to modernization.

Education is an expensive service to provide, that is why the citizens of many developing countries expect their governments to pay for education or at least bear a larger portion of the cost (Mankoe, 2005). Large sums of money are invested in the educational enterprise by the Local, State and Federal Governments in Nigeria because government has adopted education as an instrument per excellence for effecting national development (Mbipom, 2000). Thus, substantial amount of the nation's resources are committed to the education of her citizens. Egwu (2010) reported that over 30.7 billion naira was spent on the funding of basic education in the year 2009 and another 2.7 billion naira was disbursed by UBEC to over 2, 032 community projects that year. When investment is made in education, it is believed that the skills acquired would lead to an increase in the wealth of the nation. Financial resources committed to education in Kwara state in the years 2009,2010 and 2011 were $\$ 328,640,000, \quad 403,510,000$ and $\$ 340,057,150$ respectively (Kwara State of Nigeria Recurrent and Capital Estimates,2009-2011).

Secondary education is the gateway between primary and tertiary education in Nigeria. It is at that level that individuals take the courses/subjects that would qualify them for professional or vocational programmes at higher education level. Hence, there is the need to pay attention to the cost of providing such education and the efficiency of institutions utilizing the funds. Hence, 
this study examined the influence of public cost on inte nal efficiency in Kwara State public secondary schools.

\section{Review of Related Literature}

Cost is whatever that is sacrificed or incurred in order to achieve a set objective. Cost of attaining a goal may be incurred by individuals, countries, institutions or organizations, and could be in form of material resources and any other forgone alternatives. Akangbou (1985) defined cost of education as the real resources used up in the production of all human assets. Cost of education included institutional cost, private or household cost and social or public cost (Durosaro, 2012). The real cost of education refers to everything sacrificed by an individual or group on account of education.

Education cost entails direct and indirect costs. The direct cost of education is the amount of money expended in the purchase of educational goods and services. These are the direct monetary expenditures on education by governments and individuals or their parents. The indirect cost of education, on the other hand, refers to the earnings or income forgone by students when they decide to undertake an educational training programme. Garms (1987) described the indirect cost of education as the opportunity costs of schooling.

Educational cost may be either private or social in nature. Oyeniran (2008) stated that private costs of education are borne by individual students and their families brought about through payment of tuition fees, cost of books, uniforms and transport while social costs of education are borne by the public through the government. These cover all items under payment of teachers' salaries and allowances, expenditure on books, stationery and transport and on other educational goods and services.

The World Bank (1988) urged African countries to consider the idea of cost sharing instead of fully relying on public expenditure in financing education. It further observed that in many African countries most of the money allocated to education is spent on teachers' salaries with little regard to equipment, maintenance of physical facilities and development. One of the most important recommendations by the world Bank is that if African countries (South of the Sahara) were to reduce their unit costs in education at all levels they had to introduce cost sharing in which students and parents pay directly for such items as books and school running expenses. Psacharopoulos and Woodhall (1985) noted that there has been a massive increase in spending in education all over the world due to rising costs of education because of inflation, the need for more sophisticated equipment such as computers, laboratory equipment, home science materials and projectors and the ever-growing demand for education because of the recognition that education is a central element in social and economic development which has resulted in expansion of educational system.

According to Tsang (1988), given the major challenge of improving education under tight budgetary constraints, educational policymakers in developing countries today are concerned with issues regarding educational costs Using an economic framework. this paper reviews the issues and synthesizes the findings in a diverse literature on costs of educution in developing countries. 
Four key educational-cost issues are considered: (a) What are the costs of education? (b) What are the major determinants of educational costs? (c) In what ways can cost analysis improve policymaking in education? and (d) What are the informational needs for cost analysis in education? The paper concludes that although cost analysis can contribute significintly to informed decisions on education. greater efforts must be undertaken to strengthen the informational basis of cost analysis and to incorporate cost analysis in educational policy making.

Durosaro (2012) viewed education cost under capital and recurrent costs. Capital costs include cost of such items as purchase and development of school lands, school buildings, classrooms and laboratories, fixed equipment and other durable institutional equipment. These costs do not reoccur regularly, but have implications on costs in terms of maintenance costs on such fixed assets. Recurrent costs are the expenditures in educational goods and services that bring short-lived benefits usually for not more than a financial year. Resource inputs, which are current in nature, have to be reviewed periodically. Hence, expenditures on them are referred to as recurrent-operational costs since they are necessary to keep the institution going (Oyeniran, 2008).

Efficiency as a concept has its origin in economics. It is the optimal relation between inputs and outputs. The internally efficient educational system is one which turns out graduates without wasting any student-year or without dropouts or repeaters (Akinnubi, 2010). The system may be externally inefficient if the graduates turned out are not what the society, economy or higher level of education wants (Ayo, 1995).

According to Padmanabhan (2001), internal efficiency refers to the number of students who pass from one grade to the other and complete that cycle within the stipulated period of time. It shows the relationship between input and output at a given educational level. Gupta (2001) stated that the question of internal efficiency is ultimately linked to the issue of resource allocation and utilization.

The indicators of internal efficiency used by Abdulkareem (1989); Fabunmi (1999); and Afolabi (2004) are wastage rate and graduation rate. Wastage rate is caused by students who leave the school system before the completion of their courses. Wastage may also occur between grade level, as a result of students who repeat the grade and those who drop out of the system. According to Akinnubi (2010), wastage rate could be crude-cohort wastage rate or refinedcohort wastage rate. Crude-cohort wastage rate is the percentage of repeaters and drop-outs from the first year to the final year of academic sessions of a given cohort of students, while refined cohort wastage rate is the percentage of those who passed out or the graduates to the enrolment of the cohort. This is based on the fact that not all the students that reached the final year took the final year examination or passed. Graduation rate refers to the percentage of the students that finally leave the system on completion of the course to the total number that enrolled in the final grade of the level. This is very vital to the work of educational planners because it enables them to compute the input-output ratio in 
determining the efficacy of the system (Durosaro, 1997) and invariably the cost of schooling (Durosarı, 2012).

\section{Methodology}

This study was a descriptive survey type. Simple random sampling technique was used to select 10 out of the 16 Local Government Areas in the State for the Study, Furthermore, 100 out of the 187 public secondary schools in the areas were randomly selected for use. The school principals were used as respondents because they could provide required information for the conduct of the study. A researcher-designed instrument entitled: "Secondary Education Cost and Internal Efficiency Checklist" (SECIEC) was used to elicit relevant information from the respondents. The data collected were analysed using frequency counts and percentage to answer the five research questions raised, while Pearson productmoment correlation coefficient was used to test the hypothesis formulated at 0.05 level of significance.

\section{Research Questions}

The following research questions were raised to guide the conduct of the study:
2. What is the public cost of secondary education in Kwara State?

3. What is the yearly unit of public cost of edurcating a secondary school student in Kwara State between 2005 and 2009 ?

4. What are the wastage rates in Kwara State secondary schools for 2005 cohort?

\section{Research Hypothesis}

There is no significant relationship between public cost and internal efficiency in Kwara State secondary schools

\section{Results and Discussion}

Research Question 1: What are the sources of funds to finance secondary education in Kwara State?

To answer this research question, the researchers put together government budgetary allocations to secondary education sector in Kwara State during the period under study. Also, responses of school principals to the checklist on alternative sources include levies, fees and charges by the school that were fixed by the State Ministry of Education. All these data were analysed as shown in Table 1.

1. What are the sources of funds to finance secondary education in Kwara State?

Table 1: Sources of funds to finance secondary education in Kwara State

\begin{tabular}{|c|c|c|c|c|}
\hline Year & Budgetary Allocation & $\%$ ctungs: & $\begin{array}{l}\text { Levies/Fees } \\
(\mathbf{N})\end{array}$ & \% change \\
\hline 2005 & $2,173,812.972$ & 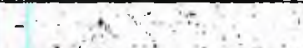 & $633,916,000$ & - \\
\hline 2006 & $3,657,046.264$ & 40.6 & $780,105.000$ & 18.7 \\
\hline 2007 & $4,542,049.549$ & 19.5 & $821,016.000$. & 5.0 \\
\hline 2008 & $6,387,355.269$ & 28.9 & $737,280.000$ & 11.4 \\
\hline 2009 & $8,790,020.140$ & 27.3 & 676.215 .000 & 9.0 \\
\hline
\end{tabular}

Source: $\quad$ Kwara State Ministry of Education Science and Technology (PRS Division) (2011). 
As shown in Table 1, budgetary allocations had been the main source of funds to finance secondary education in Kwara State. The budgetary allocation in 2006 increased by 40.6 percent above 2005 allocation. Even though, the total amount of money budgeted for secondary education continues to rise annually, but the percentage increase had continued to decline, for example, from $40.6 \%$ in 2006 to $19.5 \%$ in 2007 . It also dropped from $28.9 \%$ in 2008 to $27.3 \%$. The amount coming from other sources such as levies/fees had continued to decline, for example, from $18.7 \%$ in 2006 to $5 \%$ in 2007 and from $11.4 \%$ in 2008 to $9 \%$ in 2009.

Research Question 2: What is the public cost of secondary education in Kwara State?

Answer to this question was derived from the actual spending of government on both recurrent and capital expenditures as shown in Table 2 .

Table 2: $\quad$ Public Cost of Secondary Education in Kwara State (2005-2009)

\begin{tabular}{|c|c|c|c|c|c|}
\hline Year & $\begin{array}{l}\text { Capital Cost } \\
\text { N }\end{array}$ & $\%$ & $\begin{array}{l}\text { Recurrent Cost } \\
\end{array}$ & $\%$ & $\begin{array}{l}\text { Total Cost } \\
\text { N }\end{array}$ \\
\hline 2005 & $1,492,930,000.00$ & 40.8 & $2,164,366,264.00$ & 59.2 & $3,657,296,264.00$ \\
\hline 2006 & $2,194,593,000.00$ & 44.8 & $2,699,481,981.00$ & 55.2 & $4,894,074,981.00$ \\
\hline 2007 & $1,842,567,000.00$ & 39.2 & $2,858,284,766.00$ & 60.8 & $4,700,851,766.00$ \\
\hline 2008 & $3,529,872,299.00$ & 55.0 & $2,883,634,761.00$ & 45.0 & $6,413,507,060.00$ \\
\hline 2009 & $4,906,872,374.00$ & 62.2 & $2,979,634,760.00$ & 37.8 & $7,886,507,134.00$ \\
\hline Total & $13,966,834,673.00$ & 50.7 & $13,585,402,532.00$ & 49.3 & $27,552,237,205.00$ \\
\hline
\end{tabular}

Source: Kwara State Ministry of Education Science and Technology (PRS Division) (2011).

From Table 2, the total capital cost of secondary education was $\$ 13,966,834,673.00(50.7 \%)$ between 2005 and 2009, while recurrent cost stood at $\$ 13,585,402,530(49.3)$ over the period. The total public cost of secondary education fluctuated between 2005 and 2009, for instance, the capital cost increased from $40.8 \%$ to $44.8 \%$ in the years 2005 and 2006 and later declined to $39.2 \%$ in the year 2007 , while recurrent expenditure continued to decline over the periods.

Research question 3: What is the yearly unit cost of education a secondary school student in Kwara State between 2005 and 2009?

To answer this research question, the gross enrolment and total public cost of secondary education were computed as shown in Table 3.

Table 3: Unit of Public Cost of Secondary Education in Kwara State

\begin{tabular}{llllll}
\hline Year & Gross Enrolment & Total Public Cost & Unit Cost & $\begin{array}{c}\text { \% } \\
\text { Unit Cost }\end{array}$ \\
\hline 2005 & 138,649 & $3,657,094,264$ & $26,376,651$ & - & \\
2006 & 173,357 & $4,894,054,981$ & $28,231,078$ & 6.6 & \\
2007 & 182,448 & $4,042,541,461$ & $27,090,138$ & -4.2 & \\
2008 & 163,854 & $6,413,507,040$ & $39,141,596$ & 30.8 & \\
2009 & 150,270 & $8,886,507,140$ & $64,093,554$ & 38.9 \\
\hline
\end{tabular}


Source: $\quad$ Kwara State Ministry of Education Science and Technology (PRS Division), 2010

Table 3 shows that the public cost of educating a secondary school student in Kwara State in 2005 was $\$ 26,376,651$. This increased to $\$ 28,231,078$ in 2006 representing about $6.57 \%$ increase. The unit cost dropped by about $4.2 \%$ in 2007 but; rose in 2008 and 2009 by $30.8 \%$ and $38.9 \%$ respectively. This means that government had been spending more on per head to deliver secondary education to the citizens of the State.

\section{Research Question 5:}

What are the wastage rates in Kwara State secondary schools for 2005 cohort?

To answer this question, number of repeaters and dropouts were obtained between 2005 and 2009 as shown in Figure 1 .

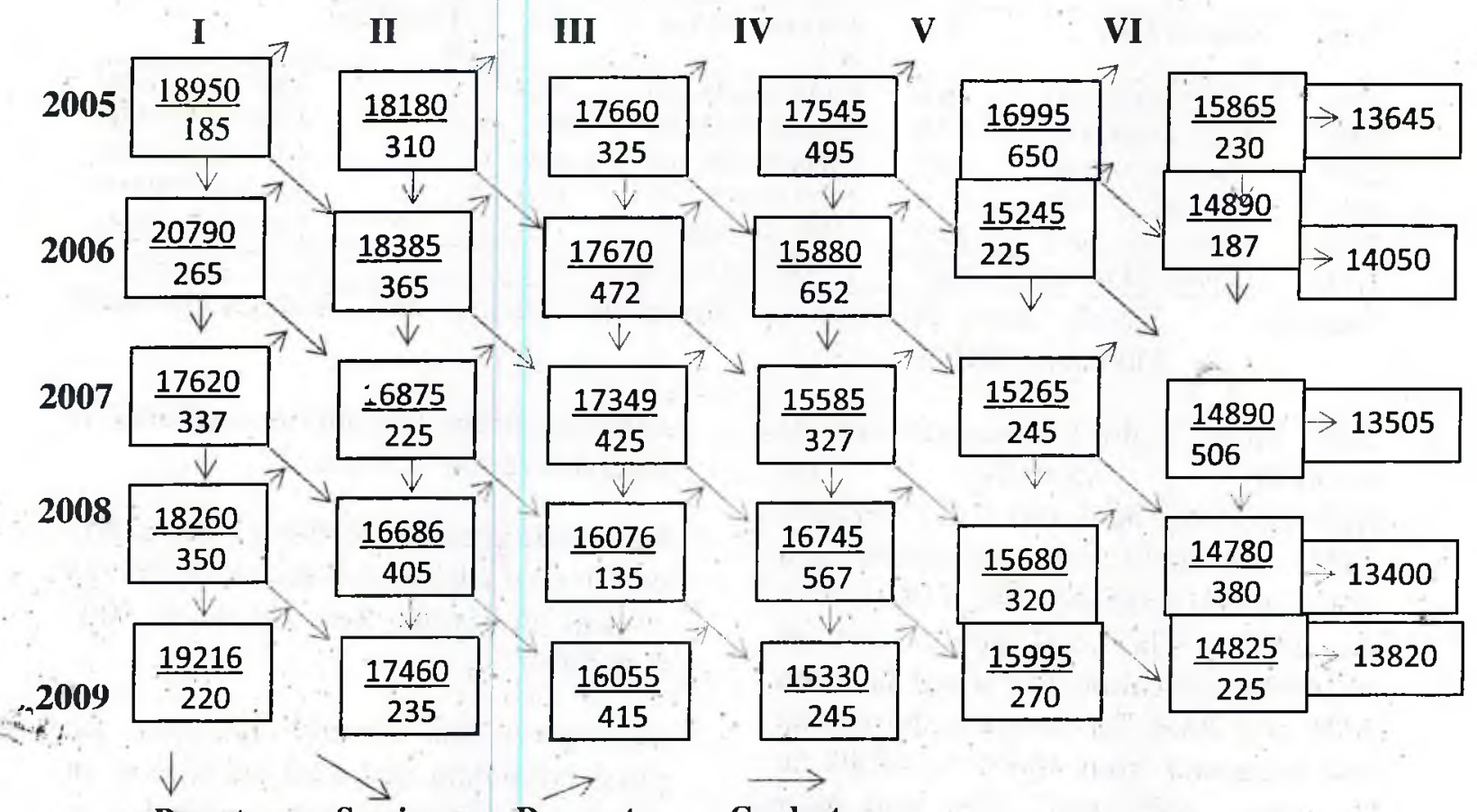

Repeaters Survivors Drop outs Graduates

Note: Values in upper case of the box represent enrolment; those in lower case represent repeaters.

Arrows represent different directions of students' movement.

Figure 1 illustrates the class enrolments and their associated rates (the promotion, repeaters and dropouts)- all shown by arrows. However, Table 4 gives a summary of the wastage rates for different classes 
Table 4: Wastage rates in Kwara State secondary schools between 2005 and 2009

\begin{tabular}{ll}
\hline Year & Wastage Rates \\
\hline WR from JS 1 to JS 2 in 2005 & 0.029 \\
WR from JS 2 to JS 3 in 2006 & 0.056 \\
WR from JS 3 to SS 1 in 2007 & 0.034 \\
WR from SS I to SS 2 in 2008 & 0.044 \\
WR from SS 2 to SS 3 in 2009 & 0.073 \\
\hline Total & $\mathbf{0 . 2 3 6}$ \\
\hline Average & $\mathbf{0 . 0 4 7}$ \\
\hline Source: $\quad$ Kwara State Ministry of Education Science and Technology (PRS
\end{tabular}

Table 4 shows that wastage rates were higher between SS 2 and SS 3 (7.3\%), and between JS 2 and JS $3(5.6 \%)$. On the average, about $4.7 \%$ of the students left school before the end of the cycle, that is, before the completion of their education programme.

\section{Research Hypothesis}

There is no significant relationship between public cost and internal efficiency in Kwara State secondary schools.

Data obtained on public cost and internal efficiency was used to test the null hypothesis through Pearson productmoment correlation statistical method at .05 level of significance as shown in Table 5 .

Table 5: Public cost and internal efficiency in Kwara State secondary schools

\begin{tabular}{|c|c|c|c|c|c|c|c|}
\hline Variable & $\mathbf{N}$ & Mean & SD & df & $\begin{array}{l}\text { Calculated } \\
\text { r-value }\end{array}$ & $\begin{array}{l}\text { Critical } \\
\text { r-value }\end{array}$ & Decision \\
\hline Public cost & 100 & 6.13 & 3.49 & 98 & 0.623 & 0.195 . & $\begin{array}{l}\text { Ho } \\
\text { Rejected }\end{array}$ \\
\hline Internal efficiency & 100 & 8.32 & 4.78 & & & & \\
\hline
\end{tabular}

As shown in Table 5, the calculated $r-$ value $(0.623)$ is greater than the critical r-value (0.195) at 0.05 level of significance and for 98 degrees of freedom. Thus, the null hypothesis is rejected. This implies that a significant relationship existed between public cost and internal efficiency in Kwara State public secondary schools. The amount of money actually invested in education sector is a good measure of efficiency of the system at a given point in time. Principal's ability to judiciously utilize the available funds will help in achieving school goals and objectives. 


\section{Conclusion}

A consistent increase in the amount of money spent on secondary education will affect both human and material inputs in education because more instructional materials will be available for the delivery of instruction, and this will lead to a general improvement in teaching and learning. To corroborate this, Mbipom (2000) remarked that large sums of money are invested in the educational enterprise by the local, State and Federal Governments in Nigeria. Public cost incurred in education is a good determinant of internal efficiency in Kwara State public secondary schools. Guptal (2001) concluded that internal efficiency is ultimately linked to the issue of resource allocation and utilization. Also, Fadipe (1992) concluded that the quality of inputs always influences the outputs of the school system. The amount of financial resource committed to the education sector has a great influence on its products at a given point in time.

\section{Recommendations}

Based on the findings of this study, the following recommendations are made:

i. Principals should judiciously utilize available funds in their disposal in order to enhance internal efficiency in Kwara State secondary schools.

ii. Government should mobilize special funds to expand and renovate the physical facilities available in schools in every part of the State in order to enhance internal efficiency in the school system.

iii. The government should evolve a more radical method of allocating funds to schools. There is the need to set criteria of getting funds from the general education budget. Such criteria could include performance indices in internal and external examinations, enrolment rate, efficiency and effectiveness factors, most especially effectiveness in the use of previous resources to attaining good educational output.

\section{References}

AbdulKareem, A. Y. (1989). Impact of school resources management on school effectiveness in selected secondary schools in Kwara State. Unpublished Ph.D. thesis, University of Ilorin, Nigeria

Afolabi, S. O. (2004). Influence of resource utilization on organizational effectiveness in Kwara State government- owned tertiary institutions. Unpublished Ph.D. thesis, University of Ilorin, Nigeria

Akangbou, S. D. (1985). Economics of educational planning in Nigeria. New Delhi: Vikas Publishing House

Akinnubi, O. P. (2010). Strategic plan implementation resource utilization and internal efficiency in Nigerian universities. Unpublished Ph.D. Thesis, University of Ilorin, Nigeria.

Ayo, A. (1995). Educational planning statistics and models. Ibadan: Keye-Yek Printing Production.

Durosaro, D. O. (1997). Statistical needs for educational planning in Nigeria. Ilorin: Corporate Office Map Publishers. 
Durosaro, D. O. (2012). Where the shoe pinches: The cost of education. The inaugural lecture. Ilorin: University of Ilorin, Nigeria.

Egwu, S. (2010, February 3). 17 million children out of schools. Punch Newspaper, p.9.

Fabunmi, F. A. (1999). The role of libraries and information centres in distance and open learning in the development of Nigeria education. E.O. Fagbamiye, J .B. Babalola, M. Fabunmi \& A. O. Ayeni (Eds.), Management of primary and secondary education in Nigeria. Ondo: NAEAP Publication.

Garms, W. (1987). School finance: The economics and politics of public education. New-Jersey: PrenticeHall.

Guptal, S. (2001). The efficiency of government expenditure: experiences from Africa. Journal of Policy Modelling, New York. 4.

Ijaiya, N. Y. S. (2012). Management that matters: Key to sustainable education. The inaugural lecture. Ilorin: University of Ilorin, Nigeria.

Kwara State of Nigeria Recurrent and Capital Estimates (2009-2011). Ministry of Finance, Ilorin, Nigeria

Kwara State Ministry of Education and Human Capital Development (MDEHCD) (2011). Kwara State budget estimate on education, 2005-2009.

Mankoe, J. O. (2006). The provision of educational resources for basic and secondary education in Ghana: Contributions from various stakeholders. Internal journal of Educational Management, 4(1).

Mbipom, G. (2000): Educational administration and planning. Calabar: University of Calabar Press.

Olutola, A. D. (1983). Cosmetic policies and the challenges of education for national development. The inaugural lecture. Ilorin: University of Ilorin, Nigeria.

Oyeniran, S. (2008). Cost and efficiency of universities in Nigeria. Unpublished Ph.D. Thesis, University of Ilorin, Nigeria.

Padmenabhan, Y. (2001). Internal efficiency of primary education. http.//www.sterieso41188eci.htm. 